\title{
Digestate Liquid Fraction Treatment with Filters Filled with Recovery Materials
}

\author{
Ilaria Piccoli ${ }^{1}\left(\mathbb{D}\right.$, Giuseppe Virga $^{2}$, Carmelo Maucieri ${ }^{1, *}$ and Maurizio Borin ${ }^{1}(\mathbb{C}$ \\ 1 Department of Agronomy, Food, Natural Resources, Animals and Environment (DAFNAE), University of \\ Padova, Viale dell’Università, 16, 35020 Legnaro, Italy; ilaria.piccoli@unipd.it (I.P.); \\ maurizio.borin@unipd.it (M.B.) \\ 2 Consorzio di Ricerca per lo Sviluppo di Sistemi Innovativi, via Libertà, 203, 90133 Palermo, Italy; \\ giuseppe.virga@corissia.it \\ * Correspondence: carmelo.maucieril@unipd.it
}

check for updates

Citation: Piccoli, I.; Virga, G.;

Maucieri, C.; Borin, M. Digestate Liquid Fraction Treatment with Filters Filled with Recovery Materials. Water 2021, 13, 21. https://doi.org/ 10.3390/w13010021

Received: 2 October 2020 Accepted: 18 December 2020 Published: 24 December 2020

Publisher's Note: MDPI stays neutral with regard to jurisdictional clai$\mathrm{ms}$ in published maps and institutional affiliations.

Copyright: (C) 2020 by the authors. Licensee MDPI, Basel, Switzerland. This article is an open access article distributed under the terms and conditions of the Creative Commons Attribution (CC BY) license (https:// creativecommons.org/licenses/by/ $4.0 /)$.

\begin{abstract}
Constructed wetlands (CWs) represent a green technology for digestate liquid fraction (DLF) treatment. However, previous research has warned about their performance when treating wastewater with high suspended solid and organic loads. In addition, the high $\mathrm{NH}_{4}-\mathrm{N}$ concentration typical of this wastewater can compromise vegetation establishment and activity. In view of this, a digestate pretreatment is needed. This study aimed to test the performance of filters filled with recovery materials, such as brick and refractory material, for DLF pretreatment. The effect on DLF physical (electrical conductivity, $\mathrm{pH}$, dissolved oxygen, and temperature) and chemical (total nitrogen, ammonia-nitrogen, nitrate-nitrogen, total phosphorus, soluble phosphorus, and chemical oxygen demand) characteristics was monitored during eight weekly cycles. The effect of filtration on total nitrogen and ammonia-nitrogen removal began after about one month of loading, suggesting that an activation period is necessary for bacteria. For effective $\mathrm{N}$ removal, the presence of multiple digestate recirculations per day through the filters appears mandatory to guarantee the alternation of nitrification and denitrification conditions. For P removal, filling material particle size appeared to be more important than its composition. Unclear performances were observed considering chemical oxygen demand. Further studies on filling media and microbial community interactions, and the long-term efficiency of filters, are desirable.
\end{abstract}

Keywords: digestate; aerobic filters; nutrients removal; wetland pretreatment

\section{Introduction}

Electricity production from biogas plants in the European Union (EU) has grown rapidly during the past 25 years, accounting for half of the global biogas production (ca. 650 PJ) in 2015 [1]. The biomass of digestate, the by-product of anaerobic digestion, is quantitatively similar to the inlet raw materials. Indeed, during anaerobic digestion, a fraction of organic carbon is transformed into methane $\left(\mathrm{CH}_{4}\right)$ and carbon dioxide $\left(\mathrm{CO}_{2}\right)$, whereas for most of the other elements, particularly nitrogen $(\mathrm{N})$ and phosphorus $(\mathrm{P})$, there is no material loss but rather a form change [2,3]. The $\mathrm{N}$ recovery in the digestate is close to $100 \%$, whereas $\mathrm{P}$, calcium $(\mathrm{Ca})$, magnesium $(\mathrm{Mg})$, and manganese $(\mathrm{Mn})$ are partially crystallized in substituted phosphate form, which can be used as P fertilizer [4]. Generally, digestates are characterized by a higher ammonium $\left(\mathrm{NH}_{4}{ }^{+}\right.$)-to-total- $\mathrm{N}(\mathrm{TN})$ ratio; stable organic matter $(\mathrm{OM})$ and $\mathrm{pH}$; and lower easily degradable $\mathrm{OM}$, total and organic carbon $(\mathrm{C})$ content, biological oxygen $\left(\mathrm{O}_{2}\right)$ demand $\left(\mathrm{BOD}_{5}\right), \mathrm{C}$-to- $\mathrm{N}$ ratio, and viscosity compared with undigested raw materials [5]. Nonetheless, digestate composition is a function of incoming biomass [6,7]. For example, the $\mathrm{NH}_{4}{ }^{+}-\mathrm{N}$ content is directly related to feedstock total $\mathrm{N}$ content. Indeed, feedstock-derived digestates are characterized by a high $\mathrm{NH}_{4}{ }^{+}-\mathrm{N}$-to-TN ratio and a low C-to-N ratio $[8,9]$ due to the high degradability of the raw materials (e.g., 
cereal grains). In contrast, cattle manures or fibrous feedstocks with low $\mathrm{N}$ content (e.g., silage maize) lead to a low $\mathrm{NH}_{4}{ }^{+}-\mathrm{N}$-to-TN ratio digestate [10].

Digestate is commonly recycled as fertilizer [11], but if its total $\mathrm{N}$ content is expected to be higher than the EU Nitrates Directive limits per spreading unit surface, it has to be treated for $\mathrm{N}$ reduction [12,13] before agriculture use. Different types of digestate treatment are reported in the literature, from liquid/solid separation to membrane filtration [14,15]. However, these are expensive to realize and maintain. Separation creates two outputsa solid and a liquid fraction - that need to be stored and handled separately [16]. The former represents about $15 \%$ of the raw digestate and is concentrated in organic matter, as organic $\mathrm{N}$ and $\mathrm{P}$, and is a valuable and easily manageable soil amendment [17]. The liquid fraction, which represents about $85 \%$ of the raw digestate, is rich in nitrogen (about $0.5 \%$ of fresh weight), mainly as ammonium (about 70\%) [18]. Considering the European Nitrates Directive limits (from 170 to $340 \mathrm{~kg} \mathrm{~N} \mathrm{ha}^{-1}$ in relation to vulnerability of spreading area) and taking into account the liquid fraction characteristics, its management is more difficult than that of the solid fraction and requires a large land area for spreading. In addition, its management implies the costs of transportation and distribution. For these reasons, the reduction in the $\mathrm{N}$ content in this fraction is of crucial importance to reduce the required land area and related costs of distribution.

Constructed wetlands (CWs) represent a green technology for digestate treatment $[19,20]$. They are engineered systems that exploit natural processes to remove organic compounds and nutrients from wastewater [21-24] and provide effective, low-cost, low-maintenance, and environmentally beneficial alternatives to traditional systems [25,26]. Despite the numerous reported benefits, previous research has warned about the long-term function of CWs as a form of treatment for wastewater characterized by high organic and suspended solid loads [27-29] as digestate $[19,30]$ due to substrate clogging. Additionally, the high $\mathrm{NH}_{4}{ }^{+}-\mathrm{N}$ and salinity content may compromise the plant survival in CWs [26]. In several papers, the digestate liquid fraction (DLF) was diluted (from 1:2 to 1:20 DLF:water) before CW treatment, and in some cases it was additionally subjected to a residence time in a sediment tank $[13,19,20,31]$ with the aim to reduce the suspended solids and $\mathrm{NH}_{4}{ }^{+}-\mathrm{N}$ concentration. However, dilution may not be considered a suitable solution in practical conditions because it implies higher volumes to store and manage. For this reason, a digestate pretreatment able to reduce the pollutant load before $\mathrm{CW}$ treatment is needed. Different pretreatment technologies are available, such as ultrafiltration, reverse osmosis, and stripping, that also allow nutrient recovery, but these are relatively complex and expensive [32] from both economic and environmental perspectives. Therefore, interest in exploring more environmentally friendly pretreatment solutions remains. A possible low-cost pretreatment system, already used for other effluents, is aerobic filtration [33,34]. Although sand-filled filters are the most commonly used approach [35-39], several investigations of on-farm and/or low-cost filtering media have been undertaken, such as wood chips, wheat straw [40], oyster shells [41], semisoft plastic media [34], rockwool [42], and materials from the recirculation of subproducts of different industrial processes (e.g., laterite [43], zeolite, and zeolitite [44,45]). In this context, the individuation of low-cost and easily available filling materials is a target that can combine the needs of developing filters for DLF pretreatment and fostering the circular economy of farms $[46,47]$. However, to our knowledge, no studies have been conducted on the use of recovery materials for filtration before DLF CW treatment.

Therefore, the aim of this study was to test the effects of recovery materials used as filtering media, such as fragmented bricks and refractories, on the main DLF chemicalphysical characteristics and to evaluate whether the resulting wastewater presents adequate characteristics to be treated with CWs.

\section{Materials and Methods}

\subsection{Filter Structure and Composition}

The experiment took place indoors from March to May 2013 and involved four aluminum filters composed of two modules each $\left(0.48 \mathrm{~m}\right.$ height, $0.48 \mathrm{~m}$ diameter, $0.08 \mathrm{~m}^{3}$ volume) (Figure 1). The upper module was a real filter containing the filling medium held 
by a steel plate mesh and covered with a plastic cap to prevent evaporation. The lower module was a tank in which the DLF was stored after filtration. Upper and lower modules were connected through a vacuum pump, which was controlled by a timer set to a $3 \mathrm{~h}$ timespan, allowing eight filtration cycles per day.
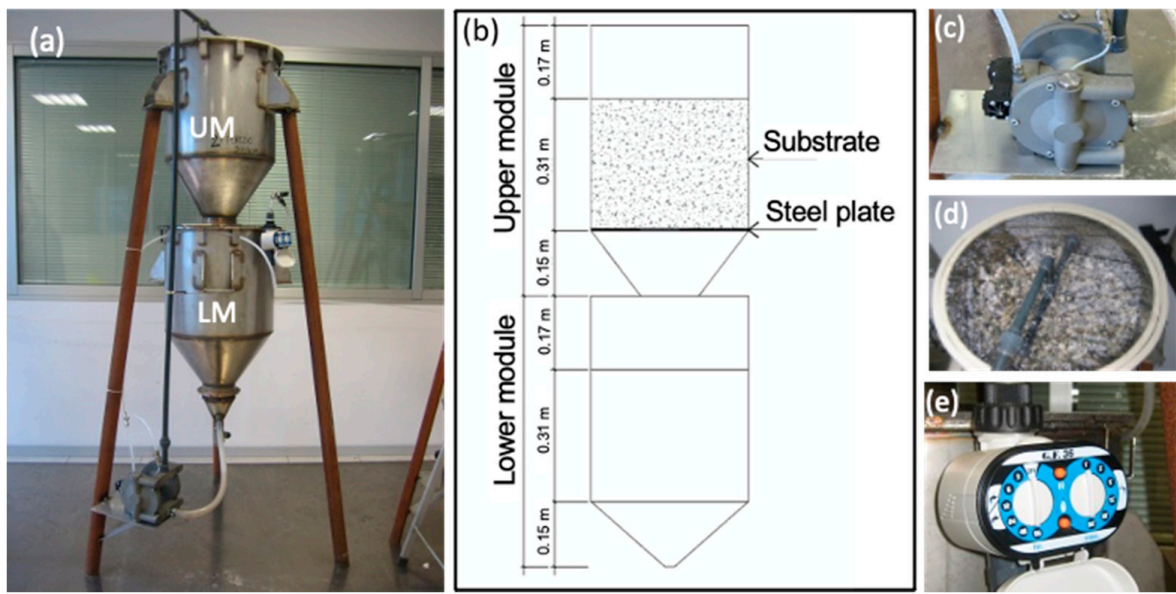

Figure 1. Description of filter structure: (a) upper (UM) and lower (LM) filter modules; (b) modules' internal structure with dimensions expressed in $\mathrm{mm}$; (c) vacuum pump; (d) plastic cap; (e) timer.

The filters were filled with three different materials, namely, brick (BRICK), porous refractory material (REFR), and gravel (GRAVEL) (Table 1). BRICK was derived from a demolition recovery industry and composed mainly of brick tiles, roof tiles, and pottery, with an average size in the $50-70 \mathrm{~mm}$ range. REFR was derived from blast furnace demolition and mainly composed of aluminum silicon oxide (51\%), magnesium aluminum silicate $(19 \%)$, and aluminum oxide (14\%), with smaller percentages of andalusite $(8 \%)$, alpha-quartz (3\%), cristobalite (4\%), and zirconium silicate (1\%). REFR presented two different dimensions: 20-30 mm (REFR 20-30) and 30-50 mm (REFR 30-50). GRAVEL was a building material of fluvial origin composed of $52 \%$ dolomite, $17 \%$ potassium aluminum silicate hydroxide, $13 \%$ calcium carbonate, $8 \%$ albite calcian, and $5 \%$ each of magnesium iron aluminum silicate hydrate and silicon oxide. Filters contained 40-89 $\mathrm{kg}$ of filling material to cover the upper module internal volume and presented a porosity between $41 \%$ (GRAVEL) and 55\% (REFR 30-50).

Table 1. Composition and characteristics of filters.

\begin{tabular}{ccccc}
\hline Filter Name & Size $(\mathbf{m m})$ & Total Weight $\mathbf{( k g )}$ & Porosity $\mathbf{( \% )}$ & Residence Time (min) \\
\hline BRICK & $50-100$ & 60 & 53 & $17^{1}$ \\
REFR 30-50 & $30-50$ & 61 & 47 & $21^{1}$ \\
REFR 20-30 & $20-30$ & 40 & 55 & $22^{1}$ \\
GRAVEL & $8-15$ & 89 & 41 & $15^{1}$ \\
\hline
\end{tabular}

$190 \%$ of digestate exits after $2 \mathrm{~min}$.

\subsection{Filter Loading}

Each week, the DLF filtered in the previous week was discharged from the lower module and a new quantity of fresh DLF was loaded in the upper module. The filter loading took place manually by removing the plastic cap and gently pouring $20 \mathrm{~L}$ of DLF into the upper module. The DLF residence time was in the 15-22 min range, but the quantity of DLF percolation was not regular during this period. Irrespective of the filling material, about $90 \%$ of DLF came out in the first $2 \mathrm{~min}$. The DLF was collected at the Bondeno (FE, Italy) biogas plant and fed with a mixture of pig slurry ( $8 \%$ ) and energy crops (e.g., silage maize) $(92 \%)$. 


\subsection{Chemical-Physical Analysis}

Monitoring took place each week for a total of eight weeks, collecting both inlet and each filter outlet. Electrical conductivity (EC), $\mathrm{pH}$, dissolved oxygen (DO), and temperature (T) were measured directly inside the lower module using a Hach Lange HQD 40d multiparameter (Hach Lange $\mathrm{GmbH}$, Berlin, Germany) with interchangeable probes according to standard methods [48]. Representative samples were collected and analyzed on-site to obtain total nitrogen $(\mathrm{TN})$, ammonia-nitrogen $\left(\mathrm{NH}_{4}-\mathrm{N}\right)$, nitrate-nitrogen $\left(\mathrm{NO}_{3}-\mathrm{N}\right)$, total phosphorus (TP), soluble phosphorus $\left(\mathrm{PO}_{4}-\mathrm{P}\right)$, and chemical oxygen demand (COD) with a Hach-Lange DR-2800 spectrophotometer (Hach Lange GmbH, Berlin, Germany) and adequate cuvette test kits (LCK 014, 338, 340, 348, 350, 514) [49] according to Din [50]. Turbidity was measured with a portable HI83414 turbidimeter (HANNA Instrument, Smithfield, RI, USA) as an indirect measure of suspended solids in the digestate. DLF samples were diluted before measurements to allow parameter values to enter into the measuring ranges. The DLF inlet and outlet volumes were measured with a graduated cylinder to allow the calculation of inlet and outlet mass as inflow or outflow concentration $\left(\mathrm{mg} \mathrm{L}^{-1}\right)$ multiplied by inflow or outflow volume $(\mathrm{L})$. These values were used to represent the daily mass trend of cumulative nitrogen forms.

\subsection{Statistical Analysis}

The data series parameters did not follow a normal distribution and, thus, were tested using the Kruskal-Wallis nonparametric test using weekly measurements as replicates. Statistical analysis was performed on parameters of both concentration and mass balance for nitrogen and phosphorus forms and COD, comparing the inlet and filter outlets. For EC, $\mathrm{pH}, \mathrm{DO}, \mathrm{T}$, and turbidity, only inlet and filter outlet values were compared. Correlations between monitored wastewater parameters were evaluated using the Spearman rank correlation. Statistical analysis was performed with Statistica software (Stat Soft. Inc., Tulsa, OK, USA), version 10.

\section{Results and Discussion}

\subsection{Digestate Physical Characteristics}

The inlet DLF EC values ranged between 24.8 and $28.4 \mathrm{mS} \mathrm{cm}^{-1}$ with a median value of $27.5 \mathrm{mS} \mathrm{cm}^{-1}$ (Table 2). This is in accordance with the literature, in which digestate from anaerobic digestion of pig slurry (digested alone or codigested with other matrices) is characterized by $20-30 \mathrm{mS} \mathrm{cm}^{-1} \mathrm{EC}$. After filtration, considering the whole experimental period, the EC median value was significantly (Kruskal-Wallis $p<0.05)$ reduced $(-26.5 \%)$ by BRICK, REFR 20-30, and GRAVEL (Table 2). It is worth noting that, although reduced by filtration, the EC value did not reach the $4 \mathrm{mS} \mathrm{cm}^{-1}$ considered to be the EC threshold for CW plant survival [51]. As is well known, the reduction in EC is related to lower ion concentration. However, in our experiment, considering the $\mathrm{N}$ and $\mathrm{P}$ forms, only $\mathrm{NH}_{4}-\mathrm{N}$ significantly influenced the EC value with a positive effect as demonstrated by the Spearman correlation $(\mathrm{R}=0.910, p<0.001)$.

Table 2. The eight-week median values of electrical conductivity (EC), $\mathrm{pH}$, dissolved oxygen (DO), temperature (T), and turbidity of digestate at the inlet (IN) and filter outlets. Different letters indicate significant differences at $p<0.05$ using the Kruskal-Wallis test.

\begin{tabular}{ccccccc}
\hline Property & Unit & IN & BRICK & REFR 30-50 & REFR 20-30 & GRAVEL \\
\hline EC & $\mathrm{mS} \mathrm{cm}^{-1}$ & $27.5 \mathrm{a}$ & $20.8 \mathrm{~b}$ & $21.6 \mathrm{a}$ & $18.7 \mathrm{~b}$ & $21.5 \mathrm{~b}$ \\
pH & - & $7.7 \mathrm{a}$ & $8.6 \mathrm{~b}$ & $8.5 \mathrm{~b}$ & $8.5 \mathrm{~b}$ & $8.3 \mathrm{a}$ \\
DO & $\mathrm{mg} \mathrm{L}^{-1}$ & $0.18 \mathrm{a}$ & $0.30 \mathrm{~b}$ & $0.21 \mathrm{~b}$ & $0.20 \mathrm{~b}$ & $0.26 \mathrm{~b}$ \\
$\mathrm{~T}$ & ${ }^{\circ} \mathrm{C}$ & $18.9 \mathrm{~ns}$ & $19.9 \mathrm{~ns}$ & $18.9 \mathrm{~ns}$ & $19.2 \mathrm{~ns}$ & $19.2 \mathrm{~ns}$ \\
Turbidity & $\mathrm{NTU}$ & $38,265 \mathrm{a}$ & $33,330 \mathrm{a}$ & $32,040 \mathrm{a}$ & $32,040 \mathrm{~b}$ & $31,190 \mathrm{~b}$ \\
\hline
\end{tabular}

ns: not significant; REFR: porous refractory material 
The $\mathrm{pH}$ of the inlet DLF was steady over time, with values between 7.6 and 7.8, a range slightly lower than that reported in the literature for animal-slurry-derived digestate (around 8) [52-54]. Aerobic filtration significantly (Kruskal-Wallis $p<0.05$ ) increased pH in all filtering materials, with the exception of GRAVEL (Table 2), which showed higher variability, ranging from 7.5 to 8.8 . The $\mathrm{pH}$ increase after filtration was probably due to both (i) the formation of ammonium carbonate $\left(\left(\mathrm{NH}_{4}\right)_{2} \mathrm{CO}_{3}\right)$ [55] and the removal of $\mathrm{CO}_{2}$ as a result of the transformation of $\mathrm{CO}_{3}{ }^{2-}$ and $2 \mathrm{H}^{+}$to $\mathrm{CO}_{2}$ and $\mathrm{H}_{2} \mathrm{O}$ [56], and (ii) the reduction of multivalent ions as $\mathrm{SO}_{4}{ }^{2-}$ [2]. It is worth nothing that nitrification and denitrification work optimally in the 7.5-8.5 and 6.5-7.5 ranges, respectively [57,58]. Thus, it is speculated that filtration allows the formation of optimal conditions for nitrification while also avoiding the possible environmental drawbacks linked with denitrification conditions (e.g., $\mathrm{N}_{2} \mathrm{O}$ emissions). The $\mathrm{pH}$ increase observed in the wastewater after filter pretreatment is not considered to compromise the subsequent CW treatment. In fact, the values are well tolerated by the main macrophytes used in the CWs [59], and the high $\mathrm{CO}_{2}$ partial pressures arising in the rhizosphere due to plants and microbial respiration $[60,61]$ are expected to reduce the $\mathrm{pH}$ value [13]. Finally, the $\mathrm{pH}$ values of DLF filter outlets were within the range obtained by Comino et al. [19] and Zhou et al. [20].

As expected, the DLF DO content was very low before filtration, with values ranging from 0.13 to $0.25 \mathrm{mg} \mathrm{L}^{-1}$. After filtration, all filtering materials demonstrated a significant (Kruskal-Wallis $p<0.05)$ DO increase, reaching a median value between 0.20 and $0.30 \mathrm{mg} \mathrm{L}^{-1}$ (Table 2). The low oxygen conditions inside the filter may favor the production of nitrite from ammonia rather than of nitrate [62]. Moreover, decreased nitrification as a result of low DO may represent a major obstacle to achieve high $\mathrm{N}$ removal in CWs [63]. It is worth noting that the tested filters were intended to be pretreatment for CWs; thus, a DO increase and, in turn, COD and $\mathrm{N}$ removal are expected in the subsequent CW treatment step [64]. The still-low DO content after pretreatment may suggest that DLF would require, as a subsequent treatment step, a vertical subsurface flow CW and/or intensified CWs (e.g., aeration, waterdrop influent, and tidal operation). Indeed, the DO concentration inside the substrate can reach $8 \mathrm{mg} \mathrm{L}^{-1}$ in an aerated CW, therefore creating optimal conditions for the nitrification-denitrification process, which needs a high $\mathrm{O}_{2}$ level, thus determining the COD consumption [65].

The temperature depended on the room temperature and was not affected by filtering materials, ranging from 12.2 to $22.0^{\circ} \mathrm{C}$ during the experimental period (Table 2 ). These temperatures fell within the optimal range for nitrifying bacteria growth, according to Reddy and Patrick [66].

The turbidity of the inlet DLF was higher than 30,000 NTU and ranged between 31,540 (first cycle) and 42,360 NTU (sixth cycle). No significant turbidity reduction was observed with BRICK and REFR 30-50 filling materials, whereas a significant (KruskalWallis $p<0.05$ ) reduction was found with REFR 20-30 and GRAVEL media. Considering the behavior of the filters during the experiment, the turbidity was lowered after filtration until the seventh cycle, which was in the range of 30,000-35,000 NTU. On the contrary, during the last monitoring cycle, the turbidity increased to $45,000 \mathrm{NTU}$ in all filters. This behavior can be explained as the release of suspended solids previously accumulated around filling material particles, suggesting that a cycle of filter washing would be required. Although a few filters significantly reduced turbidity, its value remains high (Table 2). However, this parameter is usually highly abated in subsurface flow CWs (from $70 \%$ to $85 \%$ ) [67], suggesting the use of this kind of CW after filter pretreatment. In addition, a correlation between turbidity and TP presence in wastewater has been reported [68].

\subsubsection{Nitrogen}

During the experimental period, the DLF TN concentration ranged between 3030 and $4980 \mathrm{mg} \mathrm{L}^{-1}$ in the inlet. Taking into account the supplied DLF quantity, the cumulative filter load ranged from 108 to $178 \mathrm{~g} \mathrm{~m}^{-3} \mathrm{~d}^{-1}$. Considering the median values, the inlet DLF TN content was formed by $72 \%$ of $\mathrm{NH}_{4}-\mathrm{N}$ and $7 \%$ of $\mathrm{NO}_{3}-\mathrm{N}$, confirming the review of 
Möller and Müller [2], who observed that $45-80 \%$ of TN is present in ammonia form in the DLF. Considering the whole monitoring period, the DLF TN concentration did not show significant changes after filtration (Table 3). Regarding TN dynamics, all filters reduced the TN concentration and mass after the fourth week (Figure 2a,b). A different trend was instead observed for $\mathrm{NH}_{4}-\mathrm{N}$, in which the inlet increased from the first $\left(429 \mathrm{mg} \mathrm{L}^{-1}\right)$ to the fourth week (3070 $\mathrm{mg} \mathrm{L}^{-1}$ ) and then showed a steady concentration around $3000 \mathrm{mg} \mathrm{L}^{-1}$.

Table 3. The eight-week median values of total nitrogen (TN), ammonia-nitrogen $\left(\mathrm{NH}_{4}-\mathrm{N}\right)$, and nitrate-nitrogen $\left(\mathrm{NO}_{3}-\mathrm{N}\right)$ at the inlet (IN) and filter outlets. Different letters indicate significant differences at $p<0.05$ by Kruskal-Wallis test. ns: not significant.

\begin{tabular}{cccccc}
\hline $\begin{array}{c}\text { Parameter } \\
\left(\mathbf{m g ~ L} \mathbf{-}^{-1}\right)\end{array}$ & IN & BRICK & REFR 30-50 & REFR 20-30 & GRAVEL \\
\hline $\mathrm{TN}$ & $4035 \mathrm{~ns}$ & $3290 \mathrm{~ns}$ & $3050 \mathrm{~ns}$ & $2870 \mathrm{~ns}$ & $2940 \mathrm{~ns}$ \\
$\mathrm{NH}_{4}-\mathrm{N}$ & $2910 \mathrm{a}$ & $1643 \mathrm{a}$ & $2124 \mathrm{a}$ & $960 \mathrm{~b}$ & $1398 \mathrm{a}$ \\
$\mathrm{NO}_{3}-\mathrm{N}$ & $276 \mathrm{~ns}$ & $305 \mathrm{~ns}$ & $302 \mathrm{~ns}$ & $280 \mathrm{~ns}$ & $304 \mathrm{~ns}$ \\
Parameter $_{(\mathbf{g ~ f i l t e r}}^{-1}$ ) & & & & & \\
$\mathrm{TN}$ & $80.7 \mathrm{a}$ & $62.5 \mathrm{a}$ & $57.0 \mathrm{a}$ & $51.5 \mathrm{~b}$ & $52.8 \mathrm{a}$ \\
$\mathrm{NH}_{4}-\mathrm{N}$ & $58.2 \mathrm{a}$ & $30.8 \mathrm{a}$ & $38.2 \mathrm{a}$ & $13.4 \mathrm{~b}$ & $22.6 \mathrm{a}$ \\
$\mathrm{NO}_{3}-\mathrm{N}$ & $5.5 \mathrm{~ns}$ & $5.7 \mathrm{~ns}$ & $5.7 \mathrm{~ns}$ & $5.3 \mathrm{~ns}$ & $5.6 \mathrm{~ns}$ \\
\hline
\end{tabular}
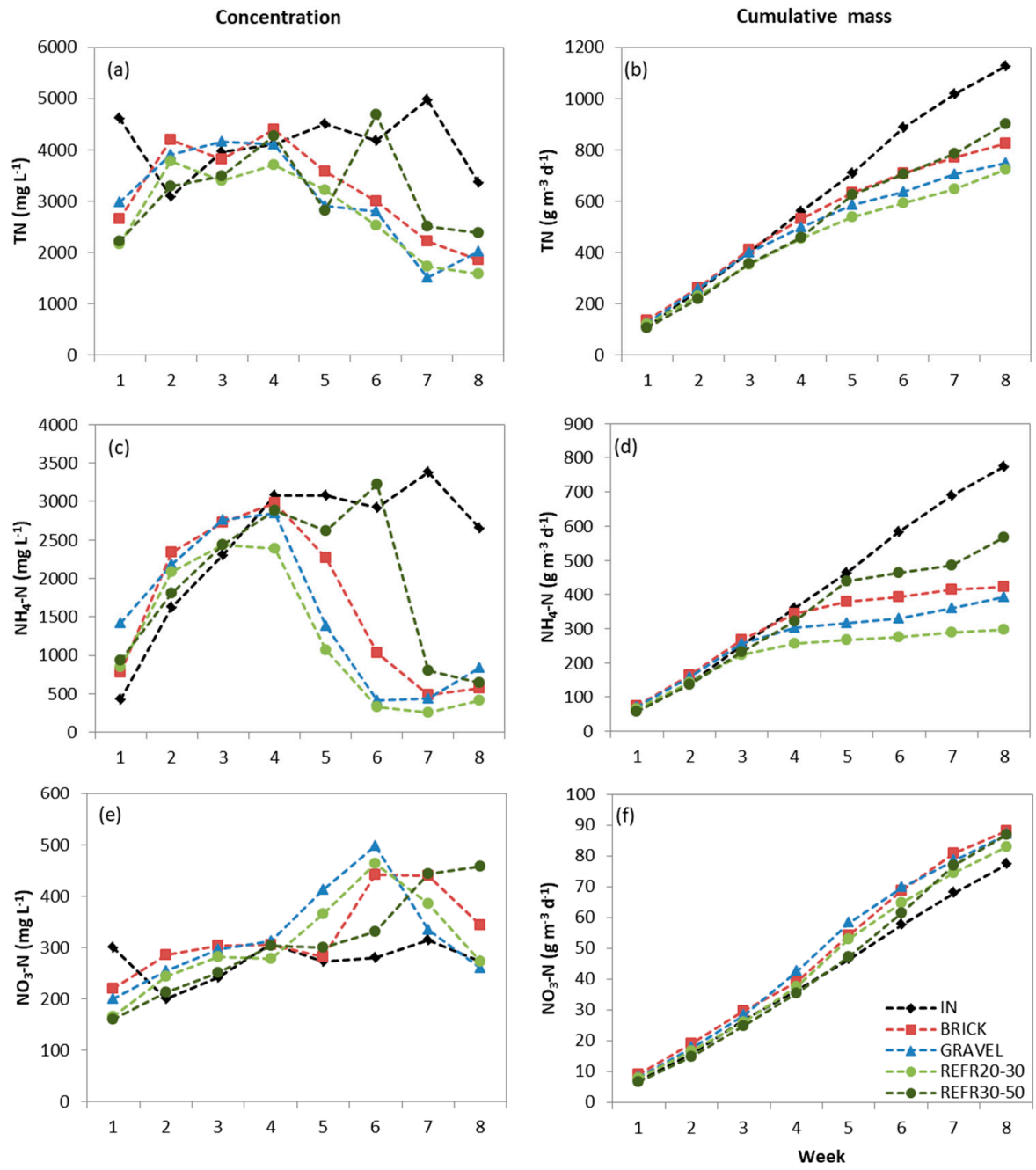

Figure 2. Total nitrogen $(\mathrm{TN})$, ammonia-nitrogen $\left(\mathrm{NH}_{4}-\mathrm{N}\right)$, and nitrate-nitrogen $\left(\mathrm{NO}_{3}-\mathrm{N}\right)$ during the eight-week experiment. Values are expressed as concentration $(\mathbf{a}, \mathbf{c}, \mathbf{e})$ and cumulative mass balance $(\mathbf{b}, \mathbf{d}, \mathbf{f})$. 
The $\mathrm{NH}_{4}-\mathrm{N}$ filter load ranged from 58 to $121 \mathrm{~g} \mathrm{~m}^{-3} \mathrm{~d}^{-1}$ (Figure 2d). Considering the whole experimental period, the $\mathrm{NH}_{4}-\mathrm{N}$ concentration and absolute DLF content were significantly reduced by filtration only when using REFR $20-30(-67.0 \%$ and $-77.0 \%$, respectively) as the filter medium. However, from the fourth experimental week, different cumulative abatement behaviors were observed among filters, ranked as follows: REFR 20-30 > GRAVEL > BRICK > REFR 30-50. In addition, regarding $\mathrm{NH}_{4}-\mathrm{N}$ concentration dynamics, a general and consistent decreasing trend was visible after the fourth week in all filters (Figure 2), in which concentrations in the DLF outlet around $400-500 \mathrm{mg} \mathrm{L}^{-1}$ were obtained. Ammonia dynamics are $\mathrm{pH}$ and temperature dependent [69]. In this study, $\mathrm{pH}$ ranged from 8.3 to 8.6 throughout the treatment period. Therefore, ammonia loss through volatilization from filters was negligible because $\mathrm{NH}_{4}-\mathrm{N}$ is generally insignificant below $7.5 \mathrm{pH}$ and losses are often not serious around $8.0 \mathrm{pH}$ [66]. The values measured at the filter outlets are similar to those obtained in studies in which DLF was diluted before CW treatment (from about 65 to $500 \mathrm{mg} \mathrm{L}^{-1}$ ) $[13,19,31]$ and do not compromise vegetation establishment and wetland functioning [24]. Thus, for $\mathrm{NH}_{4}-\mathrm{N}$, filtration pretreatment can be a valuable alternative to DLF dilution before $\mathrm{CW}$ treatment.

In contrast, the $\mathrm{NO}_{3}-\mathrm{N}$ concentration and its absolute presence in the inlet DLF were more stable over time and ranged between 200 and $314 \mathrm{mg} \mathrm{L}^{-1}$ (median value $276 \mathrm{mg} \mathrm{L}^{-1}$ ), whereas a specific dynamic was observed at each filter outlet (Figure 2e,f). Considering the whole monitoring period, neither $\mathrm{NO}_{3}-\mathrm{N}$ concentration nor $\mathrm{NO}_{3}-\mathrm{N}$ absolute content was significantly different between inlet and filter outlets (Table 3). Although not significant for $\mathrm{NO}_{3}-\mathrm{N}$, an opposite trend was observed between $\mathrm{NO}_{3}-\mathrm{N}$ (i.e., increase) and $\mathrm{NH}_{4}-\mathrm{N}$ (i.e., decrease) during the fourth to sixth week period, probably due to nitrifying bacteria growth, which implies a start-up period of about 40 days [70]. Subsequently (sixth to eighth week), the $\mathrm{NH}_{4}-\mathrm{N}$ mass content in the treated DLF was stable (Figure 2d), whereas the $\mathrm{TN}$ decreased (Figure $2 \mathrm{~b}$ ) and $\mathrm{NO}_{3}-\mathrm{N}$ slightly increased (Figure $2 \mathrm{f}$ ) compared with the inlet. Considering that filters were not vegetated, $\mathrm{N}$ removal should have been achieved through microorganisms. In addition, it can be speculated that the $\mathrm{NO}_{3}-\mathrm{N}$ mass content decrease in the last two monitoring cycles was due to denitrification. Indeed, denitrification occurs when $\mathrm{O}_{2}$ levels are depleted $\left(<0.5 \mathrm{mg} \mathrm{L}^{-1}\right)$ and $\mathrm{NO}_{3}{ }^{-}$becomes the primary oxygen source for microorganisms [63,71]. In this study, the DLF DO content was always below $0.5 \mathrm{mg} \mathrm{L}^{-1}$ and $\mathrm{N}$ form dynamics indicate that four weeks is the time period required for biological activation of the proposed filters.

\subsubsection{Phosphorus}

The inlet DLF TP concentration and weekly absolute load median values were $411.5 \mathrm{mg} \mathrm{L}^{-1}$ and $8.2 \mathrm{~g} \mathrm{filter}^{-1}$, respectively. Among the studied filtering media, only GRAVEL was able to significantly reduce both TP concentration $(-17 \%)$ and mass balance $(-23 \%)$ (Figure $3 a, b)$.

The $\mathrm{PO}_{4}-\mathrm{P}$ concentration in the inlet DLF represented $85 \%$ of the TP. Its concentration and weekly absolute load median values were $351.5 \mathrm{mg} \mathrm{L}^{-1}$ and $7.0 \mathrm{~g} \mathrm{filter}^{-1}$, respectively. $\mathrm{PO}_{4}$-P showed the same behavior observed for TP; only GRAVEL significantly reduced its content, by $29 \%$ and $34 \%$, for concentration and mass balance, respectively (Figure $3 c, d$ ). $\mathrm{P}$ removal in natural-like systems is a critical issue that has not yet been sufficiently solved and is closely associated with the properties of the filter material [72]. Indeed, $P$ removal is mainly achieved via precipitation or sorption on filtering media [72], the latter being controlled by the properties of physical-chemical substrates [73]. In addition, a microbial P uptake has also been observed [63]. In CW systems, P removal is also a critical issue because the major removal processes (i.e., adsorption on the substrate surface and precipitation) are saturable and decrease over time [63]. However, in these systems, plant uptake represents one of the key levers to improve P removal efficiency but with a species-specific effect [74]. Taking into account the high $P$ concentration still present after filtration, plants characterized by high $\mathrm{P}$ uptake should be chosen to vegetate $\mathrm{CW}$ s used to treat DLF filter outlets. 

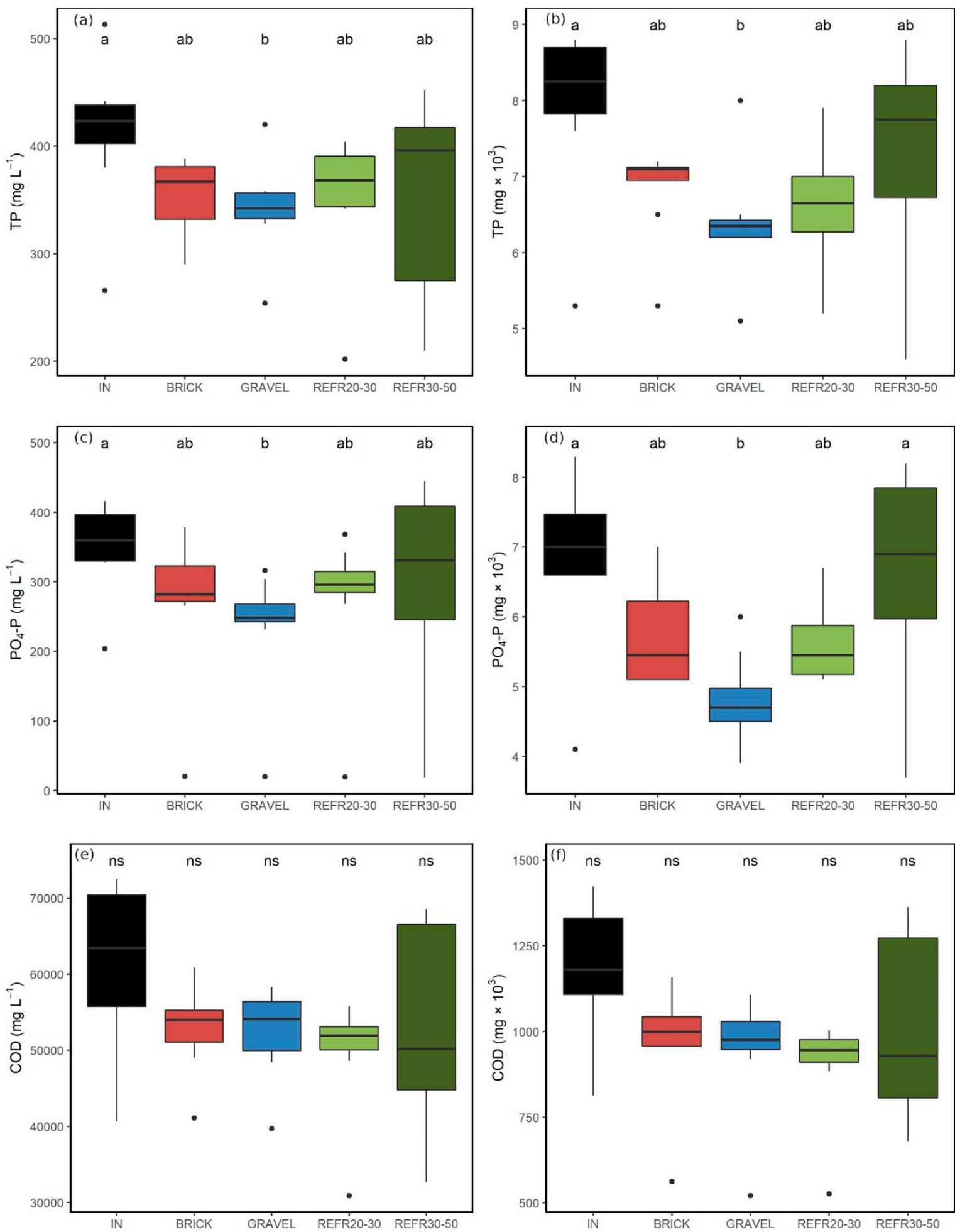

Figure 3. Box plot of total phosphorus (TP), soluble phosphorus $\left(\mathrm{PO}_{4}-\mathrm{P}\right)$, and chemical oxygen demand (COD) expressed as concentration $(\mathbf{a}, \mathbf{c}, \mathbf{e})$ and mass balance $(\mathbf{b}, \mathbf{d}, \mathbf{f})$. Different letters indicate significant differences according to a Kruskal-Wallis test with $p \leq 0.05$. ns $=$ not significant difference.

In this experiment, the best performance was achieved using GRAVEL substrate, probably due to the higher specific surface area, which increases as the particle size decreases. Indeed, GRAVEL was the material with the lowest particle size, from 2.5 to 7.5 times lower than that of all other substrates. Consequently, as already reported by Henderson et al. [75], it may be speculated that the microbial population linked to the P cycle may have a much 
greater surface area to colonize in gravel than in other substrates. Additionally, digestate recirculation through the filter led to a slight increase in $\mathrm{O}_{2}$ availability, which may have fostered microbial P uptake [76].

\subsubsection{Chemical Oxygen Demand (COD)}

The COD concentration in the inlet DLF during the monitoring period ranged between $40,620 \mathrm{mg} \mathrm{L}^{-1}$ (first cycle) and 71,170 $\mathrm{mg} \mathrm{L}^{-1}$ (fourth cycle), with a median value of $59,035 \mathrm{mg} \mathrm{L}^{-1}$. The COD quantity loaded in each filter with DLF was in the 812-1423 g range per monitoring cycle, with a median value of $1181 \mathrm{~g}$. The statistical analysis of COD concentration and mass balance did not show differences among filters, probably due to the high variability of the dataset, particularly in REFR 30-50 (Figure 3e). Indeed, removing the latter from the database, significant (Kruskal-Wallis $p<0.05$ ) COD mass removal was found in REFR 20-30. Trends of the COD mass absolute value (Figure 3f) were very similar to the concentration trends. In this study, the low COD abatement may be due to (1) the preservation of recalcitrant material during anaerobic digestion that, in turn, leads to a high content of biologically stable organic carbon (similar to that of compost) in the DLF [77], and (2) the low $\mathrm{O}_{2}$ available and high COD/TN ratio (about 15.2). The latter represents the relative quantity of carbon sources able to affect the decomposition of organics by microorganisms, as well as the microbial processes of nitrification and denitrification $[78,79]$. Therefore, the influent $\mathrm{COD} / \mathrm{N}$ ratios can promote or inhibit the microbial activity affecting the pollutant removal performance $[80,81]$. Despite the filters effect, the COD concentration was still too high in DLF, most likely due to the high quantity of suspended solids. Therefore, the effect of filtration, as managed in this research, is not yet sufficient to prepare wastewater for subsequent wetland treatment. Different options may be suggested: enhanced filtration by more recirculation and/or intensified wetlands, as previously mentioned.

\section{Conclusions}

The aerobic filters tested in this study showed encouraging results in DLF treatment, suggesting that recovery materials might also be suitable for agricultural wastewater treatment and may provide new insights into the circular economy. Although the monitoring period was limited, some preliminary results were obtained:

- DLF turbidity was lowered only by REFR 20-30 and GRAVEL filtering materials.

- EC was only slightly abated by filters, and thus remains a challenge for the establishment of $C W$ vegetation.

- The effect of filtration on $\mathrm{TN}$ and $\mathrm{NH}_{4}-\mathrm{N}$ removal began after about one month of loading, suggesting that this is the period after which bacterial activation occurs.

- $\quad$ REFR 20-30 was the only filtering material able to significantly remove $\mathrm{TN}$ and $\mathrm{NH}_{4}-\mathrm{N}$ from the DLF to values suitable for CW vegetation.

- $\quad$ For P removal, filling material particle size appeared more important than its composition. Indeed, the best performances were observed with GRAVEL.

The filters demonstrated insufficient performance for COD; therefore, further studies may verify if a smaller (e.g., $<1.5 \mathrm{~cm}$ ) particle size may be more effective. For efficient $\mathrm{N}$ removal, the presence of multiple digestate recirculations per day through the filters appears necessary to guarantee the alternation of nitrification and denitrification conditions. Further studies elucidating the interactions between filling media and microbial communities, and the long-term efficiency of filters, are required.

Author Contributions: Conceptualization, M.B.; formal analysis, I.P., G.V., and C.M.; investigation, I.P.; data interpretation, I.P., G.V., C.M., and M.B.; writing-original draft preparation, I.P. and C.M.; writing-review and editing, I.P., C.M., G.V., and M.B.; visualization, I.P. and C.M.; supervision, M.B.; funding acquisition, M.B. All authors have read and agreed to the published version of the manuscript. 
Funding: This research was funded by Progetti Fondimpresa "Sviluppo di sistemi innovativi per il trattamento di digestato, reflui zootecnici e rifiuti ceramici".

Conflicts of Interest: The authors declare no conflict of interest.

\section{References}

1. Benato, A.; Macor, A. Italian biogas plants: Trend, subsidies, cost, biogas composition and engine emissions. Energies 2019, 12, 979. [CrossRef]

2. Möller, K.; Müller, T. Effects of anaerobic digestion on digestate nutrient availability and crop growth: A review. Eng. Life Sci. 2012, 12, 242-257. [CrossRef]

3. Sánchez-Ramírez, J.E.; Pastor, L.; Martí, N.; Claros, J.; Doñate, S.; Bouzas, A. Analysis of uncontrolled phosphorus precipitation in anaerobic digesters under thermophilic and mesophilic conditions. Environ. Technol. 2019, 1-10. [CrossRef] [PubMed]

4. Marcato, C.E.; Pinelli, E.; Pouech, P.; Winterton, P.; Guiresse, M. Particle size and metal distributions in anaerobically digested pig slurry. Bioresour. Technol. 2008, 99, 2340-2348. [CrossRef]

5. Tambone, F.; Scaglia, B.; D’Imporzano, G.; Schievano, A.; Orzi, V.; Salati, S.; Adani, F. Assessing amendment and fertilizing properties of digestates from anaerobic digestion through a comparative study with digested sludge and compost. Chemosphere 2010, 81, 577-583. [CrossRef]

6. Nkoa, R. Agricultural benefits and environmental risks of soil fertilization with anaerobic digestates: A review. Agron. Sustain. Dev. 2014, 34, 473-492. [CrossRef]

7. Tampio, E.; Salo, T.; Rintala, J. Agronomic characteristics of five different urban waste digestates. J. Environ. Manag. 2016, 169, 293-302. [CrossRef]

8. Emmerling, C.; Barton, J. Anaerobic co-digestion of topinambour (Helianthus tuberosus L.) and properties of the remaining biogas manure. Arch. Agron. Soil Sci. 2007, 53, 683-690. [CrossRef]

9. De Boer, H.C. Co-digestion of animal slurry can increase short-term Nitrogen recovery by crops. J. Environ. Qual. 2008, 37, 1968-1973. [CrossRef]

10. Möller, K.; Schulz, R.; Müller, T. Substrate inputs, nutrient flows and nitrogen loss of two centralized biogas plants in southern Germany. Nutr. Cycl. Agroecosyst. 2010, 87, 307-325. [CrossRef]

11. Maucieri, C.; Barbera, A.C.; Borin, M. Effect of injection depth of digestate liquid fraction on soil carbon dioxide emission and maize biomass production. Ital. J. Agron. 2016, 11, 6-11. [CrossRef]

12. Delzeit, R.; Kellner, U. How Location Decisions Influence Transport Costs of Processed and Unprocessed Bioenergy Digestates: The Impact of Plant Size and Location on Profitability of Biogas Plants in Germany; Kiel Workingpapers: Kiel, Germany, 2011.

13. Maucieri, C.; Mietto, A.; Barbera, A.C.; Borin, M. Treatment performance and greenhouse gas emission of a pilot hybrid constructed wetland system treating digestate liquid fraction. Ecol. Eng. 2016, 94, 406-417. [CrossRef]

14. Macura, B.; Johannesdottir, S.L.; Piniewski, M.; Haddaway, N.R.; Kvarnström, E. Effectiveness of ecotechnologies for recovery of nitrogen and phosphorus from anaerobic digestate and effectiveness of the recovery products as fertilisers: A systematic review protocol. Environ. Evid. 2019, 8, 29. [CrossRef]

15. Zheng, T.; Qiu, Z.; Dai, Q.; Chen, J. Study of biogas slurry concentrated by reverse osmosis system: Characteristics, optimization, and mechanism. Water Environ. Res. 2019, 91, 1447-1454. [CrossRef] [PubMed]

16. Lukehurst, C.T.; Frost, P.; Al Seadi, T. Utilisation of digestate from biogas plants as biofertiliser. IEA Bioenergy 2010, Task 37, 1-22.

17. Badagliacca, G.; Petrovičovà, B.; Pathan, S.I.; Roccotelli, A.; Romeo, M.; Monti, M.; Gelsomino, A. Use of solid anaerobic digestate and no-tillage practice for restoring the fertility status of two Mediterranean orchard soils with contrasting properties. Agric. Ecosyst. Environ. 2020, 300, 107010. [CrossRef]

18. Maucieri, C.; Borin, M. CO2 emissions and maize biomass production using digestate liquid fraction in two soil texture types Trans. ASABE 2017, 60, 1325-1336. [CrossRef]

19. Comino, E.; Riggio, V.A.; Rosso, M. Constructed wetland treatment of agricultural effluent from an anaerobic digester. Ecol. Eng. 2013, 54, 165-172. [CrossRef]

20. Zhou, S.; Wang, C.; Liu, C.; Sun, H.; Zhang, J.; Zhang, X.; Xin, L. Nutrient removal, methane and nitrous oxide emissions in a hybrid constructed wetland treating anaerobic digestate. Sci. Total Environ. 2020, 733, 138338. [CrossRef]

21. Vymazal, J. Removal of phosphorous in constructed wetland with horizontal subsurface flow in the Czech Republic. WaterAir Soli Pollut. Focus 2004, 4, 657-670. [CrossRef]

22. Szogi, A.A.; Rice, J.M.; Humenik, F.J.; Hunt, P.G.; Stem, G. Constructed wetlands for confined swine wastewater treatment. In Proceedings of the 1999 Animal Waste Management System Symposium, Cary, NC, USA; 1999; pp. 379-383.

23. Knight, R.L.; Payne, V.W.E.; Borer, R.E.; Clarke, R.A.; Pries, J.H. Constructed wetlands for livestock wastewater management. Ecol. Eng. 2000, 15, 41-55. [CrossRef]

24. Borin, M.; Politeo, M.; De Stefani, G. Performance of a hybrid constructed wetland treating piggery wastewater. Ecol. Eng. 2013, 51, 229-236. [CrossRef]

25. Smith, K.A.; Charles, D.R.; Moorhouse, D. Nitrogen excretion by farm livestock with respect to land spreading requirements and controlling nitrogen losses to ground and surface waters. Part 2: Pigs and poultry. Bioresour. Technol. 2000, 71, 183-194. [CrossRef]

26. Healy, M.G.; Rodgers, M.; Mulqueen, J. Treatment of dairy wastewater using constructed wetlands and intermittent sand filters Bioresour. Technol. 2007, 98, 2268-2281. [CrossRef] [PubMed] 
27. Hunt, P.G.; Szögi, A.A.; Humenik, F.J.; Rice, J.M.; Matheny, T.A.; Stone, K.C. Constructed wetlands for treatment of swine wastewater from an anaerobic lagoon. Trans. Am. Soc. Agric. Eng. 2002, 45, 639-647.

28. Hunt, P.G.; Matheny, T.A.; Stone, K.C. Denitrification in a coastal plain riparian zone contiguous to a heavily loaded swine wastewater spray field. J. Environ. Qual. 2004, 33, 2367-2374. [CrossRef] [PubMed]

29. Harrington, C.; Scholz, M. Assessment of pre-digested piggery wastewater treatment operations with surface flow integrated constructed wetland systems. Bioresour. Technol. 2010, 101, 7713-7723. [CrossRef]

30. Monfet, E.; Aubry, G.; Ramirez, A.A. Nutrient removal and recovery from digestate: A review of the technology. Biofuels 2018, 9 , 247-262. [CrossRef]

31. Wu, S.; Lei, M.; Lu, Q.; Guo, L.; Dong, R. Treatment of pig manure liquid digestate in horizontal flow constructed wetlands: Effect of aeration. Eng. Life Sci. 2016, 16, 263-271. [CrossRef]

32. Fuchs, W.; Drosg, B. Assessment of the state of the art of technologies for the processing of digestate residue from anaerobic digesters. Water Sci. Technol. 2013, 67, 1984-1993. [CrossRef]

33. Sánchez, L.D.; Marin, L.M.; Visscher, J.T.; Rietveld, L.C. Low-cost multi-stage filtration enhanced by coagulation-flocculation in upflow gravel filtration. Drink. Water Eng. Sci. 2012, 5, 73-85. [CrossRef]

34. Wei, X.M.; Lin, C.; Duan, N.; Peng, Y.X.; Ye, Z.Y. Application of aerobic biological filter for treating swine farms wastewater. Procedia Environ. Sci. 2010, 2, 1569-1584. [CrossRef]

35. Liu, Q.; Mancl, K.; Tuovinen, O.H. Biomass accumulation and carbon utilization in layered sand filter biofilm systems receiving milk fat and detergent mixtures. Bioresour. Technol. 2003, 89, 275-279. [CrossRef]

36. Nakhla, G.; Farooq, S. Simultaneous nitrification-denitrification in slow sand filters. J. Hazard. Mater. 2003, 96, 291-303. [CrossRef]

37. Roseth, R. Shell sand: A new filter medium for constructed wetlands and wastewater treatment. J. Environ. Sci. Health Part A Toxic Hazard. Subst. Environ. Eng. 2000, 35, 1335-1355. [CrossRef]

38. Tao, W.; Wang, J. Effects of vegetation, limestone and aeration on nitritation, anammox and denitrification in wetland treatment systems. Ecol. Eng. 2009, 35, 836-842. [CrossRef]

39. Zheng, D.; Deng, L.W.; Fan, Z.H.; Liu, G.J.; Chen, C.; Yang, H.; Liu, Y. Influence of sand layer depth on partial nitritation as pretreatment of anaerobically digested swine wastewater prior to anammox. Bioresour. Technol. 2012, 104, 274-279. [CrossRef]

40. Saliling, W.J.B.; Westerman, P.W.; Losordo, T.M. Wood chips and wheat straw as alternative biofilter media for denitrification reactors treating aquaculture and other wastewaters with high nitrate concentrations. Aquac. Eng. 2007, 37, 222-233. [CrossRef]

41. Wang, Z.; Dong, J.; Liu, L.; Zhu, G.; Liu, C. Screening of phosphate-removing substrates for use in constructed wetlands treating swine wastewater. Ecol. Eng. 2013, 54, 57-65. [CrossRef]

42. Yasuda, T.; Kuroda, K.; Fukumoto, Y.; Hanajima, D.; Suzuki, K. Evaluation of full-scale biofilter with rockwool mixture treating ammonia gas from livestock manure composting. Bioresour. Technol. 2009, 100, 1568-1572. [CrossRef]

43. Kadam, A.M.; Nemade, P.D.; Oza, G.H.; Shankar, H.S. Treatment of municipal wastewater using laterite-based constructed soil filter. Ecol. Eng. 2009, 35, 1051-1061. [CrossRef]

44. Wang, H.; Xu, J.; Sheng, L. Purification mechanism of sewage from constructed wetlands with zeolite substrates: A review. J. Clean. Prod. 2020, 120760. [CrossRef]

45. Ferretti, G.; Galamini, G.; Medoro, V.; Coltorti, M.; Giuseppe, D.D.; Faccini, B. Impact of sequential treatments with natural and na-exchanged chabazite zeolite-rich tuff on pig-slurry chemical composition. Water 2020, 12, 310. [CrossRef]

46. Mateus, D.M.R.; Pinho, H.J.O. Evaluation of solid waste stratified mixtures as constructed wetland fillers under different operation modes. J. Clean. Prod. 2020, 253, 119986. [CrossRef]

47. Kasprzyk, M.; Gajewska, M. Phosphorus removal by application of natural and semi-natural materials for possible recovery according to assumptions of circular economy and closed circuit of P. Sci. Total Environ. 2019, 650, 249-256. [CrossRef] [PubMed]

48. APHA. Standard Methods for the Examination of Water and Wastewater, 20th ed.; American Public Health Association: Washington, DC, USA; American Water Works Association: Denver, CO, USA; Water Environment Federation: Alexandria, VA, USA, 1998.

49. Hach-Lange, C. Water Analysis Handbook; Hach Company: Loveland, CO, USA, 1989.

50. DIN (Deutsches Institut FürNormung). German Standard Methods for the Examination of Water, Wastewater and Sludge; Deutches Institut für Normung: Berlin, Germany, 1985.

51. Dayton, E.A.; Basta, N.T. Characterization of drinking water treatment residuals for use as a soil substitute. Water Environ. Res. 2001, 73, 52-57. [CrossRef] [PubMed]

52. Alburquerque, J.A.; de la Fuente, C.; Bernal, M.P. Chemical properties of anaerobic digestates affecting C and N dynamics in amended soils. Agric. Ecosyst. Environ. 2012, 160, 15-22. [CrossRef]

53. Chadwick, D.R. Digestate as a fertiliser and environmental concerns. In Anaerobic Digestion Stakeholder Workshop. Session IV: Building the Market for Digestate; Exeter University: Exeter, UK, 2007.

54. Smith, K.A.; Metcalfe, P.; Grylls, J.; Jeffrey, W.; Sinclair, A. Nutrient Value of Digestate from Farm-Based Biogas Plants in Scotland; Report for Scottish Executive Environment and Rural Affairs Department-ADA/009/06; Scottish Executive Environmental and Rural Affairs Department: Edinburgh, UK, 2007.

55. Webb, A.R.; Hawkes, F.R. Laboratory scale anaerobic digestion of poultry litter: Gas yield-loading rate relationship. Agric. Waste 1985, 13, 31-49. [CrossRef]

56. Sommer, S.G.; Husted, S. A simple model of pH in slurry. J. Agric. Sci. Camb. 1995, 124, 447-453. [CrossRef] 
57. Platzer, C. Enhanced nitrogen elimination in subsurface flow artificial wetlands-A multi stage concept. In Proceedings of the Fifth International Conference on Wetland Systems for Water Pollution Control, Vienna, Austria; 1996.

58. Paul, E.A.; Clark, F.E. Soil Microbiology and Biochemistry, 2nd ed.; Academic Press: San Diego, CA, USA, 1996 ; ISBN 0125468059.

59. Kadlec, R.H.; Wallace, S.D. Treatment Wetlands, 2nd ed.; CRC Press: Boca Raton, FL, USA, 2009; ISBN 9781566705264.

60. Boyer, M.L.H.; Wheeler, B.D. Vegetation patterns in spring-fed calcareous fens: Calcite precipitation and constraints on fertility. J. Ecol. 1989, 77, 597. [CrossRef]

61. Schot, P.P.; Wassen, M.J. Calcium concentrations in wetland groundwater in relation to water sources and soil conditions in the recharge area. J. Hydrol. 1993, 141, 197-217. [CrossRef]

62. Bernet, N.; Dangcong, P.; Delgenès, J.-P.; Moletta, R. Nitrification at low Oxygen concentration in biofilm reactor. J. Environ. Eng. 2001, 127, 266-271. [CrossRef]

63. Vymazal, J. Removal of nutrients in various types of constructed wetlands. Sci. Total Environ. 2007, 380, 48-65. [CrossRef] [PubMed]

64. Shi, W.; Li, H.; Li, A. Mechanism and influencing factors of Nitrogen removal in subsurface flow constructed wetland. Appl. Chem. Eng. 2018, 1, 9-14.

65. Zhuang, L.L.; Yang, T.; Zhang, J.; Li, X. The configuration, purification effect and mechanism of intensified constructed wetland for wastewater treatment from the aspect of nitrogen removal: A review. Bioresour. Technol. 2019, 293, 122086. [CrossRef] [PubMed]

66. Reddy, K.R.; Patrick, W.H. Nitrogen transformations and loss in flooded soils and sediments. Crit. Rev. Environ. Control. 1984, 13, 273-309. [CrossRef]

67. Parde, D.; Patwa, A.; Shukla, A.; Vijay, R.; Killedar, D.J.; Kumar, R. A review of constructed wetland on type, treatment and technology of wastewater. Environ. Technol. Innov. 2020, 101261. [CrossRef]

68. Koskiaho, J.; Puustinen, M. Suspended solids and nutrient retention in two constructed wetlands as determined from continuous data recorded with sensors. Ecol. Eng. 2019, 137, 65-75. [CrossRef]

69. Wallace, S.; Knight, R. Small-Scale Constructed Wetland Treatment Systems; IWA Publishing: London, UK, 2006.

70. Jiang, W.; Tian, X.; Li, L.; Dong, S.; Zhao, K.; Li, H.; Cai, Y. Temporal bacterial community succession during the start-up process of biofilters in a cold-freshwater recirculating aquaculture system. Bioresour. Technol. 2019, 287, 121441. [CrossRef]

71. Pramanik, B.K.; Fatihah, S.; Shahrom, Z.; Ahmed, E. Biological aerated filters (BAFs) for carbon and nitrogen removal: A review. J. Eng. Sci. Technol. 2012, 7, 428-446.

72. Vohla, C.; Kõiv, M.; Bavor, H.J.; Chazarenc, F.; Mander, Ü. Filter materials for phosphorus removal from wastewater in treatment wetlands-A review. Ecol. Eng. 2011, 37, 70-89. [CrossRef]

73. Guan, B.; Yao, X.; Jiang, J.; Tian, Z.; An, S.; Gu, B.; Cai, Y. Phosphorus removal ability of three inexpensive substrates: Physicochemical properties and application. Ecol. Eng. 2009, 35, 576-581. [CrossRef]

74. Maucieri, C.; Salvato, M.; Borin, M. Vegetation contribution on phosphorus removal in constructed wetlands. Ecol. Eng. 2020, 152, 105853. [CrossRef]

75. Henderson, C.; Greenway, M.; Phillips, I. Removal of dissolved nitrogen, phosphorous and carbon from stormwater by biofiltration mesocosms. Water Sci. Technol. 2007, 55, 183-191. [CrossRef] [PubMed]

76. Shi, X.; Fan, J.; Zhang, J.; Shen, Y. Enhanced phosphorus removal in intermittently aerated constructed wetlands filled with various construction wastes. Environ. Sci. Pollut. Res. 2017, 24, 22524-22534. [CrossRef]

77. Tambone, F.; Orzi, V.; Zilio, M.; Adani, F. Measuring the organic amendment properties of the liquid fraction of digestate. Waste Manag. 2019, 88, 21-27. [CrossRef]

78. Zhu, H.; Yan, B.; Xu, Y.; Guan, J.; Liu, S. Removal of nitrogen and COD in horizontal subsurface flow constructed wetlands under different influent $\mathrm{C} / \mathrm{N}$ ratios. Ecol. Eng. 2014, 63, 58-63. [CrossRef]

79. Chen, X.; Zhu, H.; Yan, B.; Shutes, B.; Tian, L.; Wen, H. Optimal influent COD/N ratio for obtaining low GHG emissions and high pollutant removal efficiency in constructed wetlands. J. Clean. Prod. 2020, 267, 122003. [CrossRef]

80. Fan, J.; Wang, W.; Zhang, B.; Guo, Y.; Ngo, H.H.; Guo, W.; Zhang, J.; Wu, H. Nitrogen removal in intermittently aerated vertical flow constructed wetlands: Impact of influent COD/N ratios. Bioresour. Technol. 2013, 143, 461-466. [CrossRef]

81. Wang, J.; Hou, J.; Xia, L.; Jia, Z.; He, X.; Li, D.; Zhou, Y. The combined effect of dissolved oxygen and COD/N on nitrogen removal and the corresponding mechanisms in intermittent aeration constructed wetlands. Biochem. Eng. J. 2020, 153, 107400. [CrossRef] 